\title{
WINTERING WITHOUT CROPS - THE PROBLEMS INVOLVED
}

\author{
K. R. BROWN AND A. J. HARRIS \\ Grasslands Division, DSIR, G ore
}

\section{Summary}

Wintering without annual crops is discussed in relation to pasture management practices. It is pointed out that the first, and major, problem involved is a mental attitude which alienates winter from the rest of the year. Much of the discussion is devoted to pasture growth and its control in seasons other than winter, as success or failure of any wintering programme is partly determined at these times. The ramifications of this control on subsequent wintering is pointed out. Winter management and mismanagement are discussed in relation to planned pasture use, animal feed requirements, animal treading, and pasture defoliation.

A pREREQUisite for wintering without crops is high soil fertility and this paper is confined to the discussion of grazing management practices associated with wintering without crops in areas of high fertility, either natural or induced.

Grass is a crop, permanent pasture a perennial crop, and under good management, the means by which animal products are profitably produced. Winter is only one of four seasons, and like permanent pasture, perennial. Here, then, is the first major problem associated with the theme-a mental attitude. Few people consider pasture a crop, and fewer still consider winter as an integral part of the year. Rather, pasture is taken for granted as that stuff in paddocks on which animals "tread, remove herbage (defoliate) and excrete" (Edmond, 1963), while winter is pigeon-holed as something extraordinary which must be completely alienated from the rest of the year. This is reasonable when the yield distribution curve for Southland is considered (see Fig. 1).

This curve is typified by the very deep winter trough and the high peaks in spring and early summer. Because of the mental block associated with the deep winter trough, preparation for wintering without annual crops is almost non-existent. Late spring summer, and autumn management can spell success or failure to the winter programme. There is no such thing as wintering without crops - all-grass farming is a 365-day-a-year task with winter management just one part of the job. 


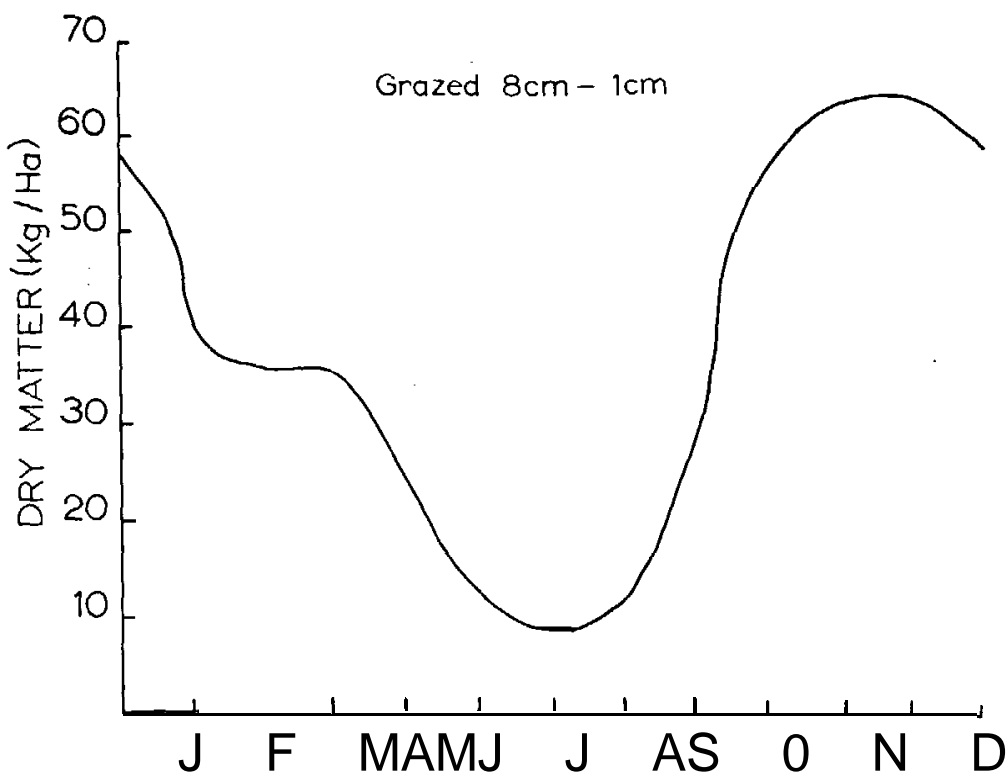

FIG. 1: Daily growth rate of perennial ryegrass/white clover throughout the year in Southland.

Wintering without annual crops in Southland is not new. Experiments carried out 15 years ago at Gore (Harris, 1960) compared hay and autumn-saved pasture with the conventional brassica crop and hay systems of wintering sheep for fat lamb production. A few farmers were prepared to accept the use of autumn-saved pasture.

The present system is a development from autumn-saved pasture but is different in that it seeks to keep pasture growing to the limits set by weather and ideally avoids the high leaf death and loss of nutritive value inherent in a system in which pasture is shut for about 90 days.

Pastures need to be composed of good species such as the ryegrasses and white clover, and they need to be moderately dense with vigorous tiller populations to achieve growth rates capable of producing $1400 \mathrm{~kg} \mathrm{DM} / \mathrm{ha}$ in the winter period of mid-May to mid-August (Fig. 1). Late spring, summer, and autumn management practices are important in bringing this about.

Summer swards which are allowed to become overlong and reproductive open up and leave bare ground into which, when 
the effect of shading is removed by grazing (see Harris and Brougham, 1968), weed grasses spread. Poa annua and browntop (Agrostis tenuis) are the most important of these. Although they produce a green cover, these species produce little in the way of winter feed. Their density is usually high (as many as 14,000 tillers $/ \mathrm{m}^{*}$ in autumn) but production can be as low as $20 \%$ of that obtained from 4,000 tillers/m* of ryegrass (Brown, 1971). Further, a sward containing many dead seed stalks, the remnants of the previous summer's mismanagement, is not the best winter feed for animals.

The consequences of poor late spring and summer management are far-reaching. Production is lowered and ryegrass vigour declines because of competition with browntop for nutrients (Jackman, 1960; Brown, 1971), and because of the dense mat-forming habit of browntop and Poa annua white clover could be restricted through shading of growing points.

Winter grazing, through the treading effect, will damage some ryegrass but at the same time remove browntop (Brown, 1968b). Because of the low initial vigour of ryegrass in swards infested with browntop (Brown 1971), delays in spring recovery, before the benefits of removing this weed become apparent, will be greater than in swards in which browntop was not present. It is doubtful if pasture mismanaged in late spring and summer will be fully productive until mid-November, the time the problem originated the previous year. In being over-mindful of winter, the manager has created problems which automatically rule out successful wintering and cause difficulties about lambing time and later when pasture intake by lambs is beginning to add to grazing pressure.

A recent experiment at Gore at a stocking rate of 18 ewes and 5 hoggets/ha showed a winter requirement of $2500 \mathrm{~kg} \mathrm{DM} / \mathrm{ha}$ if provided from pasture. This requirement is nearly double the winter production of good rygegrass/white clover pastures, so the remainder of the ration must be found from some form of conserved material. The latter can be provided by some pasture carried forward from mid- to late autumn supplemented by hay and/or silage. Besides providing necessary feed reserves for winter, cutting for hay has the added advantage of removing much reproductive growth which allows a change to the vegetative state without the drop in autumn production associated with pastures left to become vegetative again of their own accord. From the pasture control point of view, early cuts could well be conserved as silage, thus enabling conservation at a time when 
weather conditions preclude haymaking but when pasture growth rates are high. However, it may be difficult, because of timing or non-availability of contractors, to carry out haymaking or ensiling, and rather than let a pasture get out of hand it would be advisable to top long swards.

Good late spring-summer management allows pasture to have a cover of some $\mathbf{1 8}$ to $25 \mathrm{~cm}$ but, with the onset of autumn, light energy in this environment drops off dramatically from a mean daily figure of 1507 joules/cm* in February to 825 joules $/ \mathrm{cm}^{2}$ in April (Table 1, Brown, 1973) . Leaf areas required at this time to maintain pastures at maximum efficiency are lower than they are in summer (Brougham, 1958) and management calls for shorter pasture. This will reduce the effect of summer producing plants, particularly white clover and browntop, and shift the emphasis towards the more cold-weather-productive ryegrass. However, because it looks good to have some 18 to $25 \mathrm{~cm}$ of grass on some paddocks with which to face the winter, this autumn restriction is not always applied. The consequences of this are more immediate than those for uncontrolled summer growth and are as far-reaching. Death and decay of plant tissue in the base of such stands accompanied by reduced tiller density are common because there is not sufficient light to maintain the excess photosynthetic surface. Although such pastures give the impression of growth, they may lose more dry matter than they are producing (Brougham, 1956). This is an unseen problem, except on close inspection, and can lead the unsuspecting manager into a false sense of security regarding the amount of feed available. The full impact of this is not fully realized until it is found that pastures being saved for early spring are required in winter. There is no need to dwell an the consequences of this.

Going into the winter with pastures in good condition does not automatically guarantee success. There are still problems to overcome, the chief of these being overgrazing and severe treading. The effects of an ill-defined pasture management system to achieve animal requirements are dramatic. Harris and Brown (1970) demonstrated that frequent hard grazings in winter compared with moderate use reduced the amount of herbage available over a 14-week period from May until August by $600 \mathrm{~kg} \mathrm{DM} / \mathrm{ha}$. This was attributable mainly to treading damage, In the following spring, recovery of these pastures to the rate of growth achieved by those moderately grazed was delayed by 6 weeks and at the cost of a further $700 \mathrm{~kg} / \mathrm{ha}$ dry herbage. Thus enough feed was lost in the 21 weeks of the trial to have fed 5 breeding sheep/ha. 
This was on first-class permanent pasture of Ariki ryegrass and Huia white clover and it is interesting to ponder on what the results might have been if the pastures were of the type resulting from earlier mismanagement, and full of browntop, Poa annua, and weak, unvigorous ryegrass and white clover.

To some extent the requirements of sheep and pasture are in conflict during winter. Maintenance feeding of the pregnant ewe, which implies some rationing, is able to be adopted until about one month before lambing at which time the plane of nutrition should rise steadily because of the effect on the birth weight of the lamb and the health of the ewe (Wallace, 1959). To avoid the loss in pasture productivity resulting from over-use, it is essential to have some provision for off-wintering. In the early stages of gestation (May, June and July for September lambing) it is necessary, if pasture recovery rates in August are to be at a maximum, to studiously avoid overgrazing. Wintering without crops is a planned system of grazing and should include forward feed assessment. The writers have successfully estimated grazing time by assuming that, for each $1 \mathrm{~cm}$ pasture height, there are $150 \mathrm{~kg} \mathrm{DM} / \mathrm{ha}$ and that at this time of year ewe requirement is assessed as $1.1 \mathrm{~kg} \mathrm{DM} /$ day. These yield figures have been taken over a wide range of experiments at Gore and, although there are obvious errors involving sward density and composition differences, the figures are a useful guide. The corollary of these estimations is that, should there be a calculated 3 days' feed available and the sheep finish grazing to an acceptable level in 2 days, the remaining day should be spent off the pasture with or without supplement. Treading effects are most marked when there is free surface water (Edmond, 1962) so, under these conditions, the decision to shift off pasture becomes most critical.

However, in the month prior to lambing the most important factor is animal performance. At this time feed assessment is still operative and there is still a need for rationing. In the situation where 3 days' ration is grazed in 2, it is suggested that, unless ground conditions become extremely wet, the sheep should remain grazing that paddock rather than be removed. Put another way, the preference is for the pasture to take up the slack and this seems justified because of the approach of high light intensities and temperatures and hence better conditions for pasture growth, plus the knowledge that treading effects in Southland in spring are minimal (Brown, 1968a, b) .

In general terms, adoption of a rotation of about 60 days, provided grazing intensity is not severe, allows pasture regrowth 
patterns which appear adequate for high rates of stocking per unit area although the writers are somewhat critical of the prescription which advises the farmer to divide 60 by the number of paddocks he has to obtain the number of days per paddock. Although this advice recognizes that pasture may not be sufficient to meet animal needs, it suggests that the deficiency be made up with hay fed in the paddock, Faced with this choice, the animal makes the decision to overgraze the paddock before eating hay. This is simplicity of advice carried to a ridiculous extreme and it contains the inherent danger of obtaining the deleterious effects of over-grazing described previously (Harris and Brown, 1970).

Experimentally, two highly effective systems of wintering without crops have been compared this year. One system was designed to ensure that sufficient pasture would be available from mid-July onwards by having ewes confined to a ped for 6 weeks from the end of May with hay as their sole diet. Replacement hoggets were fed hay in a rack in the field with some grass. The other system utilized grass to the maximum but with provision to remove ewes to a pad with hay feeding when soil became extremely wet. In addition, because feed and planning utilization were being assessed, hay was fed, again on the pad, to supplement pasture. Hoggets in this system were fed hay with grass' in May, rotated a paddock ahead of the ewes in June, and then reverted to grass supplemented with hay at the beginning of July when it appeared that they were using more pasture than the system could afford. Both units were stocked at 18 ewes and 5 hoggets/ha.

Table 1 gives an estimate of quantities of feed consumed over the "winter" period.

TABLE 1: FEED CONSUMPTION FROM MID-MAY TO MID-AUGUST 1972 (90 DAYS)

(DM kg/animal)

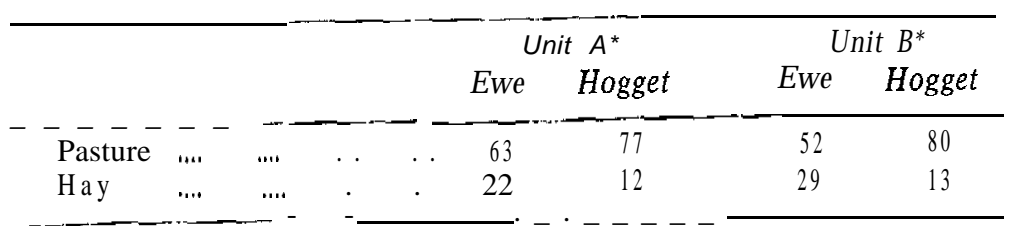

*Unit A - Ewes on pad only under extremely wet conditions.

Unit $B$ - Ewes on pad for six weeks from end of May. 
In August of this year both these systems appear successful. Unit B has more pasture available but it is estimated that there will be sufficient in Unit A although rationing will have to be enforced. Given they are both successful, there is a substantial saving in the amount of hay required in Unit $\mathrm{A}$, amounting to $131 \mathrm{~kg} / \mathrm{ha}$ or approximately 5 bales/ha.

It has not been possible to define a more progressive system of wintering hoggets and this is reflected in the changes in management adopted for these animals in Unit A. Present farming policy is generally to isolate these animals into their own system and they are either fed on brassicas supplemented with hay and grass or fed as described for Unit B. The object in rearing these animals is to achieve as high growth rates as possible and the system of grazing ahead of the ewe flock (a similar system to that followed by progressive dairy farmers) adopted in June gave an increase in liveweight for 30 days of $2.6 \mathrm{~kg}$ /animal compared with $2.0 \mathrm{~kg}$ where hay and some grass were fed. It seems possible that, with appropriate planning, the forward grazing system may be extended beyond that so far achieved.

It is believed that the general concept of wintering without crops is viable in the Southland enviranment. There are avenues where research is necessary and where improvements will be made but many of the management techniques necessary to obtain realization of the full growth potential of vigorous pastures are available now.

\section{ACKNOWLEDGEMENTS}

J. M. Johnston and M. J. Hickey, Grasslands Division, DSIR, Gore, for the use of unpublished data.

\section{REFERENCES}

Brougham, R. W., 1956: Effect of intensity of defoliation on regrowth of pasture. Aust. J. agric. Res., 7: 377-87.

1958: Interception of light by the foliage of pure and mixed stands of pasture plants. Ibid., 9: 39-52.

Brown, K. R., 1968a: The influence of herbage height at treading and treading intensity on the yields and botanical composition of a perennial ryegrass-white clover pasture. N.Z. Jl agric. Res., 11: 131-7.

1968b: Some effects of sheep treading on the herbage and seed yield of four grasses grown in association with white clover. Ibid., 1 I: $883-90$.

1971: Changes in a browntop-perennial ryegrass-white clover pasture trodden by sheep from October to March 1966-67. Ibid., 14: 828-34. 
1973: Some effects of time of sowing on the first twelve months' growth of 'Grasslands Huia' white clover sown at two seeding rates or associated with 'Grasslands Manawa' ryegrass. (In press.)

Edmond, D. B., 1962: Effect of treading pasture in summer under differ ent soil moisture levels. Ibid., 5: 389-95.

1963: Animal treading and pastures. Proc. 13th Lincoln Coll. Fmrs' Conf.: 77-81.

Harris, A. J., 1960: Some aspects of pasture production and utilisation in Southland. Proc. N.Z. Grassid Ass., 22: 53-63.

Harris, A. J.; Brown, K. R., 1970: Some effects of winter grazing management on winter and subsequent spring productivity of a ryegrasswhite clover pasture. Ibid.: 191-7.

Harris, W; Brougham, R. W., 1968: Some factors affecting change in botanical composition in a ryegrass-white clover pasture under continuous grazing. N.Z. $J l$ agric. Res., 11: 15-38.

Jackman, R. H., 1960: Competition between pasture species for nutrients from the soil. Sheepfmg A.: 75-85.

Wallace, L. R., 1959: Nutrition of grazing sheep. Proc. N.Z. Grassld Ass,: 86-96. 